\title{
Faktor-Faktor yang Berhubungan dengan Risiko Gagal Tumbuh Pada Anak Usia > 6-24 Bulan di Puskesmas Kenali Besar Kota Jambi Tahun 2016
}

\author{
Taty Nurti ${ }^{1}$, Lia Artika Sari ${ }^{2 *}$, Ika Murtiyarini ${ }^{3}$ \\ 1,2,3 Poltekkes Kemenkes Jambi Jurusan Kebidanan \\ Poltekkes Kemenkes Jambi Jurusan Kebidanan, Jl. GA Siwabessy No. 42 Jambi, Indonesia, \\ ${ }^{*}$ Correspondence email: liaartikasari@poltekkesjambi.ac.id
}

\begin{abstract}
Abstrak. Jumlah balita di Indonesia sangat besar yaitu 10 persen dari seluruh populasi. Malnultrisi masih saja melatarbelakangi penyakit dan kematian anak, meskipun masih sering luput dari perhatian. Deteksi dini penyimpangan pertumbuhan dengan melakukan pengukuran berat badan terhadap tinggi badan yang bertujuan untuk menentukan status gizi anak, Kota Jambi sendiri masih terdapat anak yang mengalami gizi buruk sebanyak 5 orang pada tahun 2015. Penelitian kuantitatif dengan desain cross sectional. Populasi adalah ibu yang mempunyai anak usia > $6-24$ bulan yang berada di wilayah Puskesmas Kenali Besar Kota Jambi. Rumus sampel menggunakan Rule of Thumb dengan koreksi dan berjumlah 80. Teknik pengambilan sampel quota sample. Hasil analisis terdapat hubungan pengetahuan dengan risiko gagal tumbuh pada anak usia $>6-24$ bulan $p$-Value $=0.011$ ( $\mathrm{p}<0.05$ ). Terdapat hubungan pemberian ASI eksklusif dengan risiko gagal tumbuh pada anak usia $>6-24 p$-Value $=0.011$ (p $<0.05$ ). tidak terdapat hubungan dukungan keluarga dengan risiko gagal tumbuh pada anak usia $>6-24$ bulan $p$-Value $=0.428$ (p $>0.05)$ di Wilayah Kerja Puskesmas Kenali Besar Kota Jambi Tahun 2016. Bagi Puskesmas agar dapat segera melaporkan apabila telah terdeteksi risiko gagal tumbuh pada anak, sehingga dapat ditanggulangi secara cepat sehingga risiko gagal tumbuh tidak terjadi pada anak tersebut.
\end{abstract}

Kata kunci: Risiko Gagal Tumbuh; Pengetahuan; ASI Eksklusif; Dukungan Keluarga.

Abstract. The number of toddlers in Indonesia is very large which is 10 percent of the entire population. Malnultrisi is still behind the disease and death of a child, although it still often goes unnoticed. Early detection of growth irregularities by measuring weight loss against height aimed at determining the nutritional status of children, Jambi City itself still has children who were malnourished as many as 5 people in 2015. Quantitative research with cross sectional design. The population is a mother who has children aged 6-24 months who are in the area of Puskesmas Kenali Besar Jambi City. The sample formula uses a Rule of Thumb with corrections and amounts to 80. Quota sample sampling technique. The results of the analysis found a knowledge relationship with the risk of failing to grow in children aged 6-24 months $p$-Value $=0.011$ ( $p>0.05)$. There is an exclusive breastfeeding relationship with the risk of failing to grow in children aged $<6-24 p$-Value $=0.011(p<0.05)$. there is no family support relationship with the risk of failing to grow in children aged 6-24 months p-Value $=0.428(p>0.05)$ in the Working Area of Puskesmas Know Besar Jambi City Year 2016. For puskesmas to be able to immediately report if there has been a risk of failing to grow in the child, so that it can be addressed quickly so that the risk of failing to grow does not occur in the child.

Keywords: Risk of Failing to Grow; Knowledge, Exclusive Breast Milk; Family Support.

\section{PENDAHULUAN}

Pembangunan kesehatan sebagai bagian dari upaya membangun manusia seutuhnya antara lain diselenggarakan melalui upaya kesehatan anak yang dilakukan sedini mungkin sejak anak masih dalam kandungan. Upaya kesehatan ibu yang dilakukan sebelum dan semasa hamil hingga melahirkan, ditujukan untuk menghasilkan keturunan yang sehat dan lahir dengan selamat. Upaya kesehatan dilakukan sejak anak masih dalam kandungan sampai berusia lima tahun pertama kehidupannya ditujukan untuk mempertahankan kelangsungan kehidupannya dan meningkatkan kualitas hidup anak tersebut, agar mencapai tumbuh kembang yang optimal baik fisik, mental, emosional maupun sosial serta memiliki intelenjensi majemuk sesuai dengan potensi genetiknya. (Kemenkes RI, 2015)

Jumlah balita di Indonesia sangat besar yaitu 10 persen dari seluruh populasi, maka sebagai calon generasi penerus bangsa, kualitas tumbuh kembang balita di Indonesia perlu mendapat perhatian khusus yaitu mendapat gizi yang baik, stimulasi yang memadai, serta terjangkau oleh pelayanan kesehatan berkualitas termasuk deteksi dan intervensi dini penyimpangan tumbuh kembang (Kemenkes RI, 2015).

Pertumbuhan adalah bertambahnya ukuran dan jumlah sel serta jaringan interseluler, berarti bertambahnya ukuran fisik dan sturktur tubuh sebagian atau keseluruhan, sehingga dapat diukur dengan satuan panjang dan berat. (Kemenkes RI, 2015)

Malnultrisi masih saja melatarbelakangi penyakit dan kematian anak, meskipun masih sering luput dari perhatian. Sebagian besar anak di dunia (sekitar 80\%) yang menderita malnutrisi bermukim di wilayah yang miskin. Meskipun persentase malnutrisi terus berkurang, angka prevalensi disebagian wilayah sesungguhnya terus 
Taty Nurti et al, Faktor-Faktor yang Berhubungan dengan Risiko Gagal Tumbuh Pada Anak Usia > 6-24 Bulan di Puskesmas Kenali Besar Kota Jambi Tahun 2016

meningkat sebanding dengan laju fertilitas. (Arisman, 2002)

Deteksi dini penyimpangan pertumbuhan dilakukan di semua tingkat pelayanan. Adapun cara mendeteksi dengan melakukan pengukuran berat badan terhadap tinggi badan (BB/TB). Tujuan pengukuran $\mathrm{BB} / \mathrm{TB}$ untuk menentukan status gizi anak, normal, kurus, kurus sekali atau gemuk. (Kemenkes RI, 2015)

Pertumbuhan adalah bertambahnya ukuran dan jumlah sel serta jaringan interseluler, berarti bertambahnya ukuran fisik dan sturktur tubuh sebagian atau keseluruhan, sehingga dapat diukur dengan satuan panjang dan berat. (Kemenkes RI, 2015)

Seorang anak dikatakan gagal tumbuh apabila pertumbuhan anak secara bermakna lebih rendah dibandingkan dengana anak seusianya. Sebagai batasan adalah dibawah - 3 SD (standar deviasi) atau pertumbuhan menurun melewati 2 pita utama, misalnya dari +1 SD ke - 1 SD dalam waktu yang singkat. Secara umum penyebab gagal tumbuh dibagi menjadi organic yaitu akibat kondisi medis dan non organic akibat gangguan psikososial. (Kemenkes RI, 2010)

Cara mendeteksi seorang anak mengalami gagal tumbuh dengan melakukan pemeriksaan fisik yang terdiri dari pemeriksaan antropometri berupa: BB/Umur: $<-2$ SD dan BB/PB: < - 2 SD. (Kemenkes RI, 2010)

Pengetahuan adalah hasil penginderaan manusia, atau hasil tahu seseorang terhadap objek melalui indera yang dimilikinya (mata, hidung, telinga, dan sebagainya). Dengan sendirinya, pada waktu penginderaan sampai menghasilkan pengetahuan tersebut sangat dipengaruhi oleh intensitas perhatian dan persepsi terhadap objek. Sebagian besar pengetahuan seseorang diperoleh melalui indera pendengaran (telinga), dan indera penglihatan (Notoadmodjo, 2010).

Pengetahuan merupakan hasil dari tahu, dan ini terjadi setelah orang melakukan penginderaan terhadap suatu objek tertentu. Penginderaan terjadi melalui pencaindera manusia, yakni indera penglihatan, penciuman, rasa, dan raba. Sebagian besar pengetahuan manusia diperoleh melalui mata dan telinga (Notoatmodjo, 2010).

Dibandingkan dengan orang dewasa, kebutuhan bayi akan zat gizi boleh dibilang sangat kecil. Namun, jika diukur berdasarkan persentase berat badan, kebutuhan bayi akan zat gizi ternyata melampaui kebutuhan orang dewasa, nyaris dua kali lipat. Makanan pertama dan utama bayi tentu saja air susu ibu. Pilihan ini tak perlu diperdebatkan lagi. Air susu ibu cocok sekali untuk memenuhi kebutuhan bayi dalam segala hal. Pemberian susu formula akan berdampak terhadap gizi anak apabila ketidaktepatan dalam mencampur susu formula dalam takaran yang tepat. Jika campuran terlalu kental dapat mengakibatkan diare hipertonik dan berdampak terjadi dehidrasi hipertonik, dan atau jika terlalu encer maka kandungan gizi akan menjadi kurang sehingga dapat mengakibatkan anak mengalami malnutrisi. (Arisman, 2002)

Bayi diatas usia 6 bulan harus dikenalkan dengan makanan pendamping ASI, karena kebutuhan gizi tidak lagi tercukupi dengan hanya pemberian ASI saja. Makanan pendamping dibutuhkan untuk memenuhi kebutuhan pangan bayi yang semakin meningkat sesuai bertambahnya umur. (Sulistyoningsih, 2011)

Pemberian MPASI baik jenis, porsi dan frekuensinya tergantung dari usia dan kemampuan bayi. Berikut ini hal-hal yang harus diperhatikan dalam memberikan MPASI agar kebutuhan gizi bayi terpenuhi dengan baik. Hal-hal yang harus diperhatikan dalam memberikan MPASI (Sulistyoningsih, 2011)

ASI eksklusif atau lebih tepat pemberian ASI secara eksklusif adalah bayi hanya diberi ASI saja, tanpa tambahan cairan lain seperti susu formula, jeruk, madu, air teh, air putih, dan tanpa tambahan makanan padat seperti pisang, pepaya, bubur susu, biskuit, bubur nasi, dan tim. (Utami Roesli, 2009)

Air susu seorang ibu secara khusus disesuaikan untuk bayinya sendiri, misalnya ASI dari seorang ibu yang melahirkan prematur komposisinya akan berbeda dengan ASI yang dihasilkan oleh ibu yang melahirkan cukup bulan. Selain itu juga komposisi ASI dari seorang ibu juga berbeda-beda dari hari ke hari. ASI yang keluar pada saat kelahiran sampai hari ke 4 atau ke 7, berbeda dengan ASI yang keluar dari hari ke 10/ke 14. Bahkan terdapat perbedaan komposisi ASI dari menit ke menit. (Utami Roesli, 2009)

ASI merupakan sumber gizi yang sangat ideal dengan komposisi yang seimbang dan disesuaikan dengan kebutuhan pertumbuhan bayi. ASI adalah makanan bayi yang paling sempurna, baik kualitas maupun kuantitasnya. Dengan tatalaksana menyusui yang benar, ASI sebagai makanan tunggal akan cukup memenuhi kebutuhan tumbuh bayi normal sampai usia 6 bulan. Setelah usia 6 bulan, bayi harus mulai diberi makanan padat, tetapi ASI dapat diteruskan sampai usia 2 tahun atau lebih. (Utami Roesli, 2009)

Otak bayi membesar dua kali lipat dalam tahun pertama kehidupan. Sel-sel otak yang banyaknya 14 miliar sel, tidak bisa tumbuh dan berkembang secara alami saja sehingga ia membutuhkan nutrisi, seperti lemak dan protein. Nutrisi yang paling bagus dan paling cocok tiada lain adalah yang terdapat dalam ASI karena ASI sangat sempurna sebagai nutrisi bagi bayi. (Nurkhasanah, 2011)

Awal tahun kehidupan bayi merupakan masa paling rawan. Di samping memenuhi kebutuhan nutrisnya, ASI juga melindungi bayi dari berbagai macam penyakit. Bayi baru lahir belum memiliki kekebalan tubuh yang sempurna, karena ada beberapa unsur penting yang masih kurang untuk melawan infeksi. ( Nurkhasanah, 2011) 
Zat kekebalan bayi baru lahir didapat dari ibunya melalui ari-ari, namun kadar ini akan cepat menurun. Pada saat zat kekebalan bawaan menurun sedangkan yang dibentuk badan belum mencukupi maka akan terjadi kesenjangan zat kekebalan pada bayi. Kesenjangan akan hilang atau berkurang apabila diberi ASI, karena ASI adalah cairan hidup yang mengandung zat kekebalan yang akan melindungi bayi dari berbagai penyakit infeksi, bakteri, virus, parasit dan jamur. (Utami Roesli, 2009)

Mengingat bahwa kecerdasan anak berkaitan erat dengan otak maka jelas bahwa faktor utama yang mempengaruhi perkembangan kecerdasan adalah pertumbuhan otak. Sementara itu, faktor terpenting dalam proses pertumbuhan termasuk pertumbuhan otak adalah nutrisi yang diberikan. Faktor-faktor yang mempengaruhi kuantitas dan kualitas nutrisi secara langsung juga dapat mempengaruhi pertumbuhan, termasuk pertumbuhan otak. (Utami Roesli, 2009)

Bayi yang sering berada dalam dekapan ibu karena menyusu akan merasakan kasih sayang ibunya. Ia juga akan merasa aman dan tentram, terutama karena masih dapat mendengar detak jantung ibunya yang telah ia kenal sejak dalam kandungan. Perasaan terlindung dan disayangi inilah yang akan menjadi dasar perkembangan emosi bayi dan membentuk kepribadian yang percaya diri dan dasar spiritual yang baik. (Utami Roesli, 2009)

Promosi dan dukungan muncul sebagai prioritas kesehatan masyarakat dalam beberapa tahun terakhir. Pada ibu yang mempunyai balita, dukungan sosial sangat dibutuhkan terutama dukungan yang diterima dari suami, karena dukungan suami dan keluarga merupakan salah satu faktor yang mempengaruhi keberhasilan ibu memberikan nutrisi yang baik buat anaknya.

Adapun dukungan yang dapat diberikan oleh suami/keluarga dapat berupa dukungan emosional, dukungan informasi, dukungan instrumental serta dukungan penilaian. (Sasnitiatri NN, 2008)

\section{METODE}

\section{Desain Penelitian}

Penelitian ini merupakan penelitian kuantitatif dengan desain cross sectional. Pendekatan ini dilakukan hanya untuk mengukur fenomena yang terjadi tanpa melalukan intervensi terhadap variabel. (Riduwan, 2010)

\section{Tempat dan Waktu penelitian}

Penelitian ini dilakukan di Puskesmas Kenali Besar Kota Jambi Tahun 2016.

\section{Populasi dan Sampel Populasi}

Populasi dalam penelitian ini adalah ibu yang mempunyai anak usia > 6 -24 bulan yang berada di Puskesmas Kenali Besar berjumlah 4.296 orang pada Tahun 2015.

\section{Sampel}

Rumus besaran sampel pada penelitian ini menggunakan Rule of Thumb dengan koreksi, dimana besar sampel adalah 5-10 kali jumlah variabel bebas yang diteliti, pada penelitian ini variabel bebas berjumlah 3 variabel. Bila variabel bebas berjumlah tiga dan prevalens diketahui sebesar 30\%, maka besar sampel adalah $24 / 0,3=80$ sampel.(Sopiyudin, 2009)

\section{Teknik pengambilan sampel}

Teknik pengambilan sampel pada penelitian ini yaitu quota sample, dimana sampel mudah ditemui dan masih dalam populasi.

\section{Kriteria Inklusi}

Adapun kriteria inklusi untuk sampel dalam penelitian ini adalah ibu mampu untuk baca tulis.

\section{Pengumpulan Data \\ Jenis Data}

Jenis data yang digunakan dalam penelitian ini adalah data primer yang diperoleh dengan pengisian kuisioner.

\section{Instrumen Penelitian}

Instrumen untuk pengumpulan data pada penelitian ini menggunakan kuesioner yang terdiri dari pertanyaan pengetahuan, pemberian ASI dan dukungan keluarga, dan untuk melihat apakah anak tersebut berisiko gagal tumbuh digunakan alat berupa timbangan, pengukuran panjang badan dan table $\mathrm{Z}$ score dari WHO.

\section{Metode Pengumpulan Data}

Cara pengumpulan data dilakukan dengan pengisian kuesioner oleh responden dan pengukuran berat badan dan panjang badan oleh petugas kesehatan. Pengumpulan data dilakukan di Puskesmas Kenali Besar Kota Jambi pada bulan Juni 2016 dalam pengumpulan data peneliti akan dibantu oleh enumerator.

\section{Analisis Data}

Data dianalisis menggunakan analisis univariat sehingga diperoleh distribusi frekuensi berdasarkan masing-masing variabel yang diteliti dan bivariat dengan uji statistik chi-squre.

\section{HASIL DAN PEMBAHASAN Analisis Univariat}

Data diperoleh dari data primer melalui pengisian kuesioner terhadap 80 responden mengenai faktor-faktor yang berhubungan dengan risiko gagal tumbuh pada anak usia > 6-24 bulan di Puskesmas Kenali Besar Kota Jambi Tahun 2016. Hasil penelitian disajikan dalam bentuk analisis univariat yang bertujuan untuk mengetahui frekuensi masing-masing variabel yang diteliti. Adapun variabel yang diteliti adalah 
Taty Nurti et al, Faktor-Faktor yang Berhubungan dengan Risiko Gagal Tumbuh Pada Anak Usia > 6-24 Bulan di Puskesmas Kenali Besar Kota Jambi Tahun 2016

pengetahuan, pemberian ASI eksklusif dan dukungan keluarga.

\section{Pengetahuan responden tentang nutrisi dan pertumbuhan}

Berdasarkan hasil penelitian diketahui frekuensi pengetahuan responden tentang nutrsi dan pertumbuhan. Untuk lebih jelasnya dapat dilihat pada tabel 1 berikut:

Tabel 1. Distribusi frekuensi pengetahuan responden tentang nutrisi dan pertumbuhan pada anak usia $>6-24$ bulan di Puskesmas Kenali Besar Kota Jambi Tahun $2016 \mathrm{n}=(80)$

\begin{tabular}{|c|c|c|c|}
\hline No & $\begin{array}{c}\text { Pengetahuan tentang nutrisi } \\
\text { dan pertumbuhan }\end{array}$ & Jumlah & $\%$ \\
\hline 1 & Tinggi & 36 & 45 \\
\hline 2 & Rendah & 44 & 55 \\
\hline \multicolumn{2}{|r|}{ Total } & 76 & 100.0 \\
\hline
\end{tabular}

Dari tabel diatas diketahui bahwa dari 80 responden sebanyak $44 \quad(55 \%)$ responden berpengetahuan rendah tentang nutrisi dan pertumbuhan anak usia >6-24 bulan di Puskesmas Kenali Besar Kota Jambi Tahun 2016.

\section{Pemberian ASI Eksklusif}

Berdasarkan hasil penelitian diketahui frekuensi responden yang memberikan ASI eksklusif. Untuk lebih jelasnya dapat dilihat pada tabel 2 berikut:

Tabel 2. Distribusi frekuensi pemberian ASI eksklusif di Puskesmas Kenali Besar Kota Jambi Tahun 2016 n=(80)

\begin{tabular}{cccc}
\hline No & $\begin{array}{c}\text { Pengetahuan tentang nutrisi } \\
\text { dan pertumbuhan }\end{array}$ & Jumlah & $\mathbf{\%}$ \\
\hline 1 & ASI eksklusif & 22 & 27,5 \\
2 & Tidak ASI Eksklusif & 58 & 72.5 \\
& Total & $\mathbf{8 0}$ & $\mathbf{1 0 0 . 0}$ \\
\hline
\end{tabular}

Dari tabel diatas diketahui bahwa dari 80 responden sebanyak $22(27,5 \%)$ responden memberikan ASI eksklusif di Puskesmas Kenali Besar Kota Jambi Tahun 2016.

\section{Dukungan Keluarga}

Berdasarkan hasil penelitian diketahui frekuensi dukungan keluarga dalam pemberian nutrisi pada anak. Untuk lebih jelasnya dapat dilihat pada tabel 3 berikut:

Tabel 3. Distribusi frekuensi dukungan keluarga responden tentang nutrisi dan pertumbuhan pada anak usia $>6-24$ bulan di Puskesmas Kenali Besar Kota Jambi Tahun 2016 n=(80)

\begin{tabular}{cccc}
\hline No & Dukungan Keluarga & Jumlah & \% \\
\hline 1 & Tidak mendapat dukungan & 27 & 33,75 \\
2 & Mendapat dukungan & 53 & 66,25 \\
& Total & $\mathbf{8 0}$ & $\mathbf{1 0 0 . 0}$ \\
\hline
\end{tabular}

Dari tabel diatas diketahui bahwa dari 80 responden sebanyak $53 \quad(66,25 \%)$ responden mendapatkan dukungan keluarga tentang nutrisi dan pertumbuhan anak usia >6-24 bulan di Puskesmas Kenali Besar Kota Jambi Tahun 2016.

\section{Risiko gagal tumbuh}

Berdasarkan hasil penelitian diketahui frekuensi risiko gagal tumbuh pada anak usia $>6-24$ bulan di Puskesmas Kenali Besar Kota Jambi Tahun 2016. Untuk lebih jelasnya dapat dilihat pada tabel 4 berikut:

Tabel 4. Distribusi frekuensi risiko gagal tumbuh pada anak usia >6-24 bulan di Puskesmas Kenali Besar Kota Jambi Tahun $2016 \mathrm{n}=(80)$

\begin{tabular}{|c|c|c|c|}
\hline No & $\begin{array}{c}\text { Pengetahuan tentang nutrisi } \\
\text { dan pertumbuhan }\end{array}$ & Jumlah & $\%$ \\
\hline 1 & Tidak Berisiko & 66 & 82,50 \\
\hline 2 & Berisiko & 14 & 17.50 \\
\hline & Total & 80 & 100.0 \\
\hline
\end{tabular}

Dari tabel diatas diketahui bahwa dari 80 responden sebanyak $14(17,50 \%)$ anak usia $>6-24$ bulan berisiko mengalami gagal tumbuh di Puskesmas Kenali Besar Kota Jambi Tahun 2016.

\section{Hasil Analisis Bivariat}

Hubungan pengetahuan dengan risiko gagal tumbuh pada anak usia >6-24 bulan di Puskesmas Kenali Besar Kota Jambi Tahun 2016

Analisis ini bertujuan untuk mengetahui hubungan terhadap variabel, dengan menggunakan "chi square" hasil analisis dapat dilihat pada tabel 5 berikut:

Tabel 5. Hubungan pengetahuan responden tentang nutrisi dan pertumbuhan dengan risiko gagal tumbuh pada anak usia >6-24 bulan di Puskesmas Kenali Besar Kota Jambi Tahun $2016 \mathrm{n}=(80)$

\begin{tabular}{|c|c|c|c|c|c|}
\hline \multirow{3}{*}{ Variabel } & \multicolumn{4}{|c|}{ Gagal Tumbuh } & \multirow{3}{*}{ Kemaknaan (p) } \\
\hline & \multicolumn{2}{|c|}{ Tidak Beresiko } & \multicolumn{2}{|c|}{ Risiko } & \\
\hline & $\mathrm{n}$ & $\%$ & $\mathrm{~N}$ & $\%$ & \\
\hline \multicolumn{6}{|l|}{ Pengetahuan } \\
\hline 1. Rendah & 32 & 72.72 & 12 & 27.28 & 0.011 \\
\hline 2. Tinggi & 34 & 94.44 & 2 & 5.56 & \\
\hline
\end{tabular}

Hasil analisis hubungan pengetahuan responden tentang nutrisi dan pertumbuhan pada anak usia >6-24 bulan diketahui hasil uji statistik diperoleh $p$-Value $=$ 0.011 ( $\mathrm{p}<0.05$ ). Hasil uji ini menunjukan adanya hubungan pengetahuan tentang nutrisi dan pertumbuhan dengan risiko gagal tumbuh di Puskesmas Kenali Besar Kota Jambi Tahun 2016.

Hubungan pemberian ASI eksklusif dengan risiko gagal tumbuh pada anak usia >6-24 bulan di Puskesmas Kenali Besar Kota Jambi Tahun 2016

Analisis ini bertujuan untuk mengetahui hubungan terhadap variabel, dengan menggunakan "chi square" hasil analisis dapat dilihat pada tabel 6 berikut: 
Taty Nurti et al, Faktor-Faktor yang Berhubungan dengan Risiko Gagal Tumbuh Pada Anak Usia > 6-24 Bulan di Puskesmas Kenali Besar Kota Jambi Tahun 2016

Tabel 6. Hubungan pemberian ASI eksklusif dengan risiko gagal tumbuh pada anak usia >6-24 bulan di Puskesmas Kenali Besar Kota Jambi Tahun 2016 n=(80)

\begin{tabular}{lcccccc}
\hline & \multicolumn{5}{c}{ Gagal Tumbuh } & \\
\cline { 2 - 5 } \multicolumn{1}{c}{ Yariabel } & Tidak Beresike & \multicolumn{2}{c}{ Risike } & Kemaknaan (p) \\
\cline { 2 - 5 } & $\mathrm{n}$ & $\%$ & $\mathrm{~N}$ & $\%$ & \\
\hline Pemberian ASI eksklusif & & & & & \\
1. ASI eksklusif & 22 & 100 & 0 & 0 & 0.011 \\
2. Tidak ASI eksklusif & 44 & 75.86 & 14 & 24.14 & \\
\hline
\end{tabular}

Hasil analisis hubungan pemberian ASI eksklusif dengan risiko gagal tumbuh pada anak usia $>6-24$ bulan diketahui hasil uji statistik diperoleh $p$-Value $=0.011(\mathrm{p}$ $<0.05$ ). Hasil uji ini menunjukan adanya hubungan pemberian ASI eksklusif dengan risiko gagal tumbuh di Puskesmas Kenali Besar Kota Jambi Tahun 2016.

Hubungan dukungan keluarga dengan risiko gagal tumbuh pada anak usia >6-24 bulan di Puskesmas Kenali Besar Kota Jambi Tahun 2016

Analisis ini bertujuan untuk mengetahui hubungan terhadap variabel, dengan menggunakan "chi square" hasil analisis dapat dilihat pada tabel 7 berikut:

Tabel 7. Hubungan pemberian ASI eksklusif dengan risiko gagal tumbuh pada anak usia >6-24 bulan di Puskesmas

Kenali Besar Kota Jambi Tahun 2016 n= (80)

\begin{tabular}{|c|c|c|c|c|c|}
\hline \multirow{3}{*}{ Variabel } & \multicolumn{4}{|c|}{ Gagal Tumbuh } & \multirow{3}{*}{ Kemaknaan (p) } \\
\hline & \multicolumn{2}{|c|}{ Tidak Beresike } & \multicolumn{2}{|c|}{ Risike } & \\
\hline & n & $\%$ & $\mathrm{~N}$ & $\%$ & \\
\hline \multicolumn{6}{|l|}{ Dulungan Keluarga } \\
\hline 1. Tidak Mendapat dukungan & 21 & 77.78 & 6 & 22.22 & \\
\hline 2. Mendapat dukungan & 45 & 84.90 & 8 & 15.10 & 0.428 \\
\hline
\end{tabular}

Hasil analisis hubungan dukungan keluarga dengan risiko gagal tumbuh pada anak usia $>6-24$ bulan diketahui hasil uji statistik diperoleh $p$-Value $=0.428(\mathrm{p}$ $>0.05$ ). Hasil uji ini menunjukan tidak adanya hubungan dukungan keluarga dengan risiko gagal tumbuh di Wilayah Kerja Puskesmas Kenali Besar Kota Jambi Tahun 2016.

\section{Pembahasan}

Hubungan pengetahuan dengan risiko gagal tumbuh pada anak usia >6-24 bulan di Puskesmas Kenali Besar Kota Jambi Tahun 2016.

Hasil penelitian menunjukan bahwa ibu yang memiliki pengetahuan baik rendah maupun tinggi samasama mempunyai resiko anaknya mengalami gagal tumbuh. Hasil uji statistik menunjukkan bahwa terdapat hubungan antara pengetahuan dengan risiko gagal tumbuh.

Pengetahuan atau kognitif merupakan domain yang sangat penting dalam membentuk tindakan seseorang (Notoatmojo: 2007). Kualitas pengetahuan yang dimiliki oleh ibu mempunyai peran yang krusial dalam pemberian nutrisi pada anaknya, dengan nutrisi yang baik dapat menunjang pertumbuhan dan perkembangan anak. Pengetahuan yang baik akan menyaring kebiasaan-kebiasaan atau mitos-mitos yang tidak baik mengenai pemberian nutrsi pada anak.

Pengetahuan adalah sebagai suatu pembentukan yang terus menerus oleh seseorang yang setiap saat mengalami reorganisasi karena adanya pemahamanpemahaman baru, tetapi pengetahuan saja belum cukup jika tidak diimbangi dengan sikap yang positif. Ketidaktahuan dan pengertian yang salah dalam pembuatan formula, makanan, pemberian jus buah yang berlebihan, mitos dan kepercayaan mengenai pola makan akan mempengaruhi nutrisi yang diterima oleh anak, hal ini merupakan salah satu penyebab risiko gagal tumbuh. (Kemenkes RI, 2010)

Nutrisi yang baik untuk anak usia dibawah 6 bulan adalah ASI, setelah anak berusia diatas 6 bulan pemberian ASI ditambah dengan MPASI, namum MPASI yang baik harus sesuai dengan tahapan usia anak baik dari jenis, porsi dan frekuensinya. (Sulistyoningsih, 2011). Kurangnya pengetahuan ibu dalam memberikan nutrisi akan berdampak terhadap risiko gagal tumbuh, anak yang mengalami gagal tumbuh dapat mengalami defisit perkembangan, gangguan kognitif, prestasi yang rendah pada saat sekolah dan saat dewasa menjadi tidak produktif sehingga dapat mempengaruhi pertumbuhan ekonomi suatu bangsa. (Lestari Indah R, 2016)

\section{Hubungan pemberian ASI eksklusif dengan risiko gagal tumbuh pada anak usia >6-24 bulan di Puskesmas Kenali Besar Kota Jambi Tahun 2016}

Hasil analisis pemberian ASI eksklusif dengan risiko gagal tumbuh pada anak usia >6-24 bulan terdapat hubungan yang bermakna. Pemberian ASI eksklusif dapat mencegah terjadinya risiko gagal tumbuh dimana ASI merupakan sumber gizi yang sangat ideal dengan komposisi yang seimbang dan disesuaikan dengan kebutuhan pertumbuhan bayi. ASI adalah makanan bayi yang paling sempurna, baik kualitas maupun kuantitasnya. Dengan tatalaksana menyusui yang benar, ASI sebagai makanan tunggal akan cukup memenuhi kebutuhan tumbuh bayi normal sampai usia 6 bulan. Setelah usia 6 bulan, bayi harus mulai diberi makanan padat, tetapi ASI dapat diteruskan sampai usia 2 tahun atau lebih. (Utami Roesli, 2009)

Pemerintah mengupayakan adanya perbaikan gizi penduduk Indonesia melalui program gerakan 1000 hari pertama kehidupan (HPK), yaitu program gizi yang dimulai sejak janin berada didalam kandungan sampai anak berusia 2 tahun (Lestari Indah R, 2016). Otak bayi membesar dua kali lipat dalam tahun pertama kehidupan. Sel-sel otak yang banyaknya 14 miliar sel, tidak bisa 
Taty Nurti et al, Faktor-Faktor yang Berhubungan dengan Risiko Gagal Tumbuh Pada Anak Usia > 6-24 Bulan di Puskesmas Kenali Besar Kota Jambi Tahun 2016

tumbuh dan berkembang secara alami saja sehingga ia membutuhkan nutrisi, seperti lemak dan protein. Nutrisi yang paling bagus dan paling cocok tiada lain adalah yang terdapat dalam ASI karena ASI sangat sempurna sebagai nutrisi bagi bayi.( Nurkhasanah, 2011)

Pemberian ASI eksklusif dapat mengurangi kejadian risiko gagal tumbuh sehingga bayi-bayi yang diberikan ASI eksklusif dan setelah 6 bulan mendapatkan makanan tambahan secara baik akan terhindar dari kejadian risiko gagal tumbuh.

\section{Hubungan dukungan keluarga dengan risiko gagal tumbuh pada anak usia >6-24 bulan di Puskesmas Kenali Besar Kota Jambi Tahun 2016}

Hasil penelitian menunjukan bahwa dukungan yang diberikan keluarga yaitu suami atau orangtua dalam pemberian nutrisi dan pemantauan pertumbuhan dengan risiko gagal tumbuh tidak ada hubungan yang bermakna.

Salah satu pendukung keberhasilan pertumbuhan dan perkembangan anak adalah suami yang merupakan orang terdekat yang memainkan peran kunci selama kehamilan, persalinan dan setelah bayi lahir termasuk pemantauan tumbuh kembang anak. Dukungan yang diberikan suami akan mempengaruhi kondisi psikologis ibu yang akan berdampak terhadap tumbuh kembang anak. (Sari Artika L, 2012). Namun dari hasil penelitian ini dukungan keluarga tedekat tidak mempunyai makna, hal ini bisa saja disebabkan karena yang paling menunjang dalam pertumbuhan anak adalah nutrisi, dan biasanya yang menentukan nutrisi untuk anak dalam keluarga adalah ibu.

Keluarga yang merupakan orang terdekat ibu terutama ayah dan orangtua perlu juga diberikan informasi tentang pentingnya nutrisi yang baik oleh petugas kesehatan sehingga dengan pengetahuan tersebut dapat menghilangkan anggapan-anggapan yang salah dalam pola pengasuhan terutama pemberian zat gizi pada anak. Keterlibatan aktif ayah menurun secara drastis pada masa pasca melahirkan, karena sebagaian ayah mengganggap para ibu sudah cukup mampu melakukan sendiri. Hal ini disebabkan oleh budaya yang ada, dimana peran perempuan masih menjadi sub ordinat dari peran kaum laki-laki dan masih banyaknya bias gender pada proses pengasuhan anak, yaitu hanya wanita yang bertanggung jawab dalam proses pengasuhan anak. (Sari Artika L, 2012)

\section{SIMPULAN}

Dari hasil penelitian didapatkan kesimpulan sebagai berikut:

1. Terdapat hubungan antara pengetahuan dengan risiko gagal tumbuh pada anak usia >6-24 bulan di Puskesmas Kenali Besar Kota Jambi tahun 2016.

2. Terdapat hubungan antara pemberian ASI eksklusif dengan risiko gagal tumbuh pada anak usia $>6-24$ bulan di Puskesmas Kenali Besar Kota Jambi tahun 2016.

3. Tidak terdapat hubungan antara dukungan keluarga dengan risiko gagal tumbuh pada anak usia >6-24 bulan di Puskesmas Kenali Besar Kota Jambi tahun 2016.

\section{DAFTAR PUSTAKA}

Arisman, MB (2002). Gizi dalam daur kehidupan. EGC Hariyani Sulistyoningsih. (2011). Gizi untuk kesehatan ibu dan anak. Graha Ilmu Yogyakarta

Kementerian Kesehatan RI (2010). Pedoman Penanganan Kasus Rujukan Kelainan Tumbuh Kembang Balita.

Kementerian Kesehatan RI (2015). Pedoman Pelaksanaan Stimulasi, Deteksi dan Intervensi Dini Tumbuh Kembang Anak di Tingkat Pelayanan Kesehatan Dasar.

Lestari Indah Restika (2016). Faktor risiko kejadian stunted pada anak usia 7-24 bulan di Desa Hargorejo, Kecamatan Kokap Kabupaten Kulonprogo, Yogyakarta (Skripsi)

Muhammad Sopiyudin Dahlan (2009). Besar sampel dan cara pengambilan sampel. Jakarta:Sagung Seto.

Notoatmodjo S (2007). Promosi Kesehatan dan ilmu perilaku. PT Rineka Cipta. Jakarta.

Notoatmodjo S. (2010). Promosi Kesehatan, Teori dan Aplikasi. PT Rineka Cipta. Jakarta.

Nurkhasanah (2011). ASI atau susu formula ya?. Jakarta.

Riduwan (2010). Dasar-dasar statistika. Bandung: Alfabeta.

Sari Artika Lia (2012). Faktor-faktor penentu yang berhubungan dengan pemberian ASI eksklusif di Wilayah Perkebunan Kabupaten Sarolangu 2012 (Tesis)

Sasnitiatri NN (2008). Pengaruh pengetahuan, sikap, nyeri dan dukungan terhadap keberhasilan menyusui dini pada ibu primipara di bidan praktik swasta kecamatan Bogor Barat [tesis]. Universitas Padjadjaran.

Utami Roesli (2009). Mengenal ASI eksklusif. Jakarta: Trubus Agriwidiya. 